\title{
Palaeomagnetic investigations in South-East Greenland
}

\author{
George E. J. Beckmann
}

In connection with a reconnaissance mapping programme (Bridgwater et al., this report) palaeomagnetic collections have been made of Precambrian rocks and Tertiary dykes in the Nagssugtoqidian mobile belt of the Angmagssalik region between $65.6^{\circ}$ and $66.3^{\circ} \mathrm{N}$ latitude and $35.5^{\circ}$ and $37.8^{\circ} \mathrm{W}$ longitude.

\section{The material}

A total of 642 orientated samples were collected using a portable rock drill; at 25 localities the orientation was carried out with a sun-compass (Stone, 1967), and at 17 localities with a magnetic compass in conjunction with topographic sighting.

The rock types at these 42 sites are as follows: 22 gneisses including granulite facies and amphibolite facies varieties, 6 dyke amphibolites (metamorphosed Kangâmiut dykes), 2 leuconorites from the Angmagssalik igneous complex, 2 post-tectonic granites, and associated basic rocks, 1 pseudotachylite of unknown age and 9 Tertiary dykes. Directions of magnetisation will be determined for every stably magnetised sample together with the directions and intensities of the components of the magnetic susceptibility ellipsoid.

\section{Aims of the project}

The main object of the work will be to make comparisons with the considerable palaeomagnetic knowledge now available for the Precambrian of West Greenland. It is hoped the combination of all the results will establish the fine structure of an important part of the apparent polar wander path for Greenland and this might lead to an advance in knowledge of its thermal history. The Tertiary dykes have been sampled in the hope of shedding new light on the opening of the North Atlantic Ocean. These 9 dykes fall into two sets, 4 with strikes in the range $20^{\circ}-40^{\circ}$ and 5 in the range $70^{\circ}-100^{\circ}$; possibly this observation indicates an age difference which may be resolvable palaeomagnetically.

There are two main reasons for making the susceptibility measurements. The first is to correct the directions of magnetisation for the effect of anisotropy of susceptibility by a new method developed by the author. Secondly it is hoped that it may prove feasible to use the susceptibility results as a petrofabric tool to assist in tectonic interpretations; 10 of the gneiss sites have been collected in collaboration with $\mathbf{J}$. Watterson with a view to assessing this possibility. Additionally there is the opportunity of relating the susceptibility results to airborne total magnetic intensity measurements.

\section{Preliminary results}

Palaeomagnetic measurements have been completed on the Tertiary dykes and the pseudotachylyte. All the Tertiary dykes are reversely magnetised, in common with the majority of the lavas and dykes in the Brito-Arctic Tertiary province. Magnetic cleaning has 
been carried out using partial alternating field demagnetisation. This has revealed very stable magnetisation and exceptionally precise grouping of directions at each site. The strikes of the dykes are not related to their magnetisation. The mean palaeomagnetic pole for all the dykes is not significantly different from that of the East Greenland basalts (Hailwood, 1977). However the reservation must be added that the grouping is somewhat non-Fisherian. This is a very common feature of palaeomagnetic results from the British Tertiary province which has been attributed to the detailed behaviour of the Tertiary geomagnetic field. Such behaviour may account for the fact that the pole for one of the Angmagssalik dykes lies far from the other eight. If this result is set aside the grouping of poles is quite good and yields a mean which is significantly different from the basalts at the 95 per cent confidence level. It has been argued (Soper et al., 1976) that the eruption of the East Greenland basalts marks the initiation of plate separation between Greenland and north-west Europe. A possible explanation for the palaeomagnetic difference between the basalts and the dykes at Angmagssalik is that the latter were intruded at a later stage of sea-floor spreading. This suggestion seems feasible in view of the recognition of two swarms differing in age in the Skaergaard area (Nielsen, 1975).

The pseudotachylyte is also very stably magnetised. After cleaning, the palaeomagnetic pole is typical of the early Precambrian of Greenland. It lies in the vicinity of those of the Godthåb gneisses (Fahrig \& Bridgwater, 1976), the Nordre Strømfjord gneisses (Beckmann et al., in prep.) and the norite at Angmagssalik of this study. Apparently this is the first palaeomagnetic work on a pseudotachylyte and the result contributes to knowledge of the geological history of the Angmagssalik district.

\section{Acknowledgments}

These rocks have been collected during the tenure of a Leverhulme Fellowship which is much appreciated. I thank our Engineering Staff for preparing my equipment for the expedition.

\section{References}

Beckmann, G. E. J., Olesen, N. Ø. \& Sørensen, K. in prep: A palaeomagnetic experiment on crustal uplift in the Nagssugtoqidian province of West Greenland.

Fahrig, W. F. \& Bridgwater, D. 1976: Late Archaean - Early Proterozoic palaeomagnetic pole positions from West Greenland. In Windley, B. F. (edit.) The Early History of the Earth, 427-439. London: John Wiley \& Sons.

Hailwood, E. A. 1977: Configuration of the geomagnetic field in early Tertiary times. Jl geol. Soc. Lond. $133,23-36$.

Nielsen, T. F. D. 1975: Possible mechanism of continental breakup in the North Atlantic. Nature 253, 182-184.

Soper, N. J., Downie, G., Higgins, A. C. \& Costa, L. I. 1976: Biostratigraphic ages of Tertiary basalts on the east Greenland continental margin and their relationship to plate separation in the Northeast Atlantic. Earth Planet. Sci. Lett. 32, 149-157.

Stone, D. B. 1967: A sun-compass for the direct determination of geographic north. J. Sci. Instrum. 44, $661-662$. 